\title{
CITED EDITIONS OF VIRGINIA WOOLF
}

Chapters follow the Harcourt Brace editions of Woolf, unless otherwise specified in each chapter's 'Works Cited' or 'Further Reading'.

\begin{tabular}{|c|c|}
\hline$R O O$ & A Room of One's Own \\
\hline$B A$ & $\begin{array}{l}\text { Leonard Woolf, Beginning Again: An Autobiography of the Years } \\
\text { 1911-1918 }\end{array}$ \\
\hline$B P$ & Virginia Woolf, Books and Portraits \\
\hline$B T A$ & Between the Acts \\
\hline$C D B$ & Virginia Woolf, The Captain's Death Bed and Other Essays \\
\hline$C E 1-4$ & Virginia Woolf, Collected Essays, 1-4 vols \\
\hline $\mathrm{CH}$ & $\begin{array}{l}\text { Virginia Woolf: The Critical Heritage, ed. Robin Majumdar and } \\
\text { Allen McLaurin }\end{array}$ \\
\hline$C H N 1-24$ & Charleston Neresletter, vols 1-24 \\
\hline$C M$ & The Charleston Magazine \\
\hline$C R 1$ & Virginia Woolf, The Common Reader \\
\hline CR2 & Virginia Woolf, The Common Reader, Second Series \\
\hline$C S$ & $\begin{array}{l}\text { Virginia Woolf, Congenial Spirits: The Selected Letters of Virginia } \\
\text { Woolf }\end{array}$ \\
\hline$C W$ & Virginia Woolf, Contemporary Writers \\
\hline$D 1-5$ & Virginia Woolf, The Diary of Virginia Woolf, 1-5 vols \\
\hline$D A W$ & $\begin{array}{l}\text { Leonard Woolf, Downhill All the Way: An Autobiography of the } \\
\quad \text { Years 1919-1939 }\end{array}$ \\
\hline$D M$ & Virginia Woolf, The Death of the Moth and Other Essays \\
\hline$E 1-5$ & Virginia Woolf, The Essays of Virginia Woolf, vols 1-5 \\
\hline$F$ & Virginia Woolf, Flush \\
\hline$F W$ & Virginia Woolf, Freshwater. A Comedy \\
\hline$G$ & $\begin{array}{l}\text { Leonard Woolf, Growing: An Autobiography of the Years 1904 to } \\
1911\end{array}$ \\
\hline$G R$ & Virginia Woolf, Granite al \\
\hline$H H$ & Virginia Woolf, A Haunted House and Other Short Stories \\
\hline
\end{tabular}


JNAM Leonard Woolf, The Journey not the Arrival Matters: An Autobiography of the Years 1939-1969

JR Virginia Woolf, Jacob's Room

L1-6 Virginia Woolf, The Letters of Virginia Woolf, 1-6 vols

LWL Leonard Woolf, The Letters of Leonard Woolf

$M \quad$ Virginia Woolf, The Moment and Other Essays

MD Virginia Woolf, Mrs Dalloway

MDP Virginia Woolf, Mrs Dalloway's Party

MELYM Virginia Woolf, Melymbrosia: An Early Version of the Voyage Out $M O B \quad$ Virginia Woolf, Moments of Being

ND Virginia Woolf, Night and Day

O Virginia Woolf, Orlando

$P \quad$ Virginia Woolf, The Pargiters

$P A \quad$ Virginia Woolf, A Passionate Apprentice

PH Virginia Woolf, Pointz Hall: The Earlier and Later Typescripts of Between the Acts

QB1/2 Quentin Bell, Virginia Woolf: A Biography (2 vols)

$R F \quad$ Virginia Woolf, Roger Fry

RN Brenda Silver (ed.), Virginia Woolf's Reading Notebooks

$S \quad$ Leonard Woolf, Sowing: An Autobiography of the Years 1880-1904

SF Virginia Woolf, The Complete Shorter Fiction of Virginia Woolf

TG Virginia Woolf, Three Guineas

TTL Virginia Woolf, To the Lighthouse

VO Virginia Woolf, The Voyage Out

VWB Virginia Woolf Bulletin (Virginia Woolf Society of Great Britain)

VWM Virginia Woolf Miscellany

W Virginia Woolf, The Waves

WF Virginia Woolf, Women and Fiction

$Y \quad$ Virginia Woolf, The Years 